\title{
Validity, sensitivity and resolution limit of the PCR-RFLP analysis of the rrs (16S rRNA gene) as a tool to identify soil-borne and plant-associated bacterial populations
}

\author{
Phil Oger ${ }^{\mathrm{a}}$, Yves Dessaux ${ }^{\mathrm{a} *}$, Annick Petit ${ }^{\mathrm{a}}$, Louis Gardan ${ }^{\mathrm{b}}$, \\ Charles Manceau ${ }^{\mathrm{b}}$, Cécil Chomel ${ }^{\mathrm{c}}$, Xavier Nesme ${ }^{\mathrm{c}}$ \\ ${ }^{a}$ Institut des sciences végétales, CNRS, avenue de la Terrasse, \\ 91198 Gif-sur-Yvette cedex, France \\ b Station de pathologie végétale, Inra, 42, rue Georges Morel, \\ 49071 Beaucouzé cedex, France \\ c Laboratoire d'écologie microbienne des sols, \\ Université Claude Bernard-Lyon-1, UMR CNRS 5557, \\ Inra, boulevard du 11 novembre, 69622 Villeurbanne cedex, France
}

\begin{abstract}
The value of the restriction fragment length polymorphism (RFLP) analysis of polymerase chain reaction ( $\mathrm{PCR}$ )-amplified rrs (16S ribosomal ribonucleic acid [rRNA] gene) for the rapid identification of bacteria isolated from soil or plants, and the limits of this technique, were evaluated using bacterial genera characteristic of the above-mentioned ecosystems. Results showed that up to two restriction site differences may occur between rrs operons within the same bacterial genome as well as between bacteria belonging to the same genospecies. In spite of these limited differences, members of the same genospecies yield very similar rrs RFLP patterns. The identification limit varies according to the analyzed taxa. Species can be differentiated amongst members of both the family Rhizobiaceae and the genus Stenotrophomonas, while the technique only allows grouping of closely related species amongst Xanthomonas spp. and amongst species related to Pseudomonas syringae. On the basis of their rrs RFLP profiles, all presently known species of Agrobacterium can be routinely identified using only the enzymes HpaII (or MspI), AluI and HaeIII. Moreover, the method was also found to be valuable in assessing the biodiversity of a bacterial community isolated from the rhizosphere. From the comparison of empiric rrs RFLPs, published sequences and deoxyribonucleic acid (DNA) pairing studies, we suggest that the occurrence of five different restriction sites within two rrs genes is
\end{abstract}

* Correspondence and reprints 
the minimum difference required to clearly establish that two relevant bacteria belong to different genospecies. (c) Inra/Elsevier, Paris

\section{PCR-RFLP / 16S / rrs / Agrobacterium / Pseudomonas / Xanthomonas}

Résumé - Examen critique de l'analyse par RFLP du gène déterminant l'ARN 16S. L'intérêt et les limites de l'identification bactérienne basée sur l'analyse du gène codant pour l'ARN ribosomique $16 \mathrm{~S}$ par PCR-RFLP ont été évalués dans plusieurs genres bactériens typiques des écosystèmes sol et plante. Les résultats montrent qu'il peut y avoir jusqu'à deux sites de restriction différents entre les gènes rrs de bactéries appartenant à la même espèce génomique ou entre différents opérons d'un même génome. Les résultats permettent cependant d'identifier les bactéries jusqu'au niveau de l'espèce chez les Rhizobiaceae et chez Stenotrophomonas, et jusqu'au niveau du groupe d'espèces apparentées d'un même genre chez Xanthomonas et dans le groupe apparenté à $P$. syringae. De plus, la méthode s'est révélée parfaitement adaptée pour identifier et classer les bactéries isolées d'un peuplement rhizosphérique, en permettant une identification approchée du genre, voire de l'espèce. La comparaison des données de PCR-RFLP avec les données de séquences et d'hybridations ADNADN suggèrent qu'un minimum de cinq sites de restriction polymorphes dans le gène $16 \mathrm{~S}$ est nécessaire pour affirmer que des bactéries appartiennent à des espèces génomiques différentes. (C) Inra/Elsevier, Paris

PCR-RFLP / 16S rrs / Agrobacterium / Pseudomonas / Xanthomonas

\section{INTRODUCTION}

Evaluating the diversity and defining the structure and behaviour of microbial communities have been and still remain primary objectives in microbial ecology. This assertion is particularly valid when applied to soil-borne and plant-associated bacteria, which are involved in the major biochemical cycles or exercise known beneficial or detrimental effects such as biodepollution, symbiotic nitrogen fixation or induction of human, animal or plant diseases. Indeed, soil and plant microflora are probably amongst the main reservoirs of biodiversity. However, this microbial world remains largely unexplored and therefore poorly understood: Ward et al. (1990) estimated that no more than $10 \%$ of soil bacteria have already been identified. This lack of data may be correlated with the shortage of tools to rapidly identify bacteria - and more crucially - to assess the behaviour of given bacterial population(s) amongst microbial communities of complex ecosystems.

Presently, the definition of bacterial species relies essentially on the results of deoxyribonucleic acid (DNA) pairing studies. For Wayne et al. (1987), two bacteria belong to the same species when their DNA-DNA relatedness is higher than $70 \%$ (with $\Delta T m<5{ }^{\circ} \mathrm{C}$ ). Unfortunately, hybridisation-based techniques are generally tedious and time-consuming. The determination of the DNA pairing does not constitute an exception to this rule. Furthermore, it is solely a comparative method which always calls for the availability of DNA from reference strains. Consequently, this method is not appropriate to assess rapidly the phylogenic position of new isolates. The emergence of molecular techniques, particularly those dealing with the analysis of the sequence of parts of the bacterial ribosomal ribonucleic acid (rRNA) gene operon, have shed new light 
on these questions (Woese, 1987; Normand et al., 1992; Stackebrandt et al., 1993). DNA sequencing of this part of the bacterial genome provides scientists with numerous data on the genetic distance separating bacteria, a feature which has led to a drastic revision of Aristotle's fixed image of the 'species'. Moreover, the availability of sequence data from a growing number of bacterial species ensures that any new strain may readily be positioned somewhere in the life tree without the absolute requirement of additional biochemical analysis. This is of primary importance when exploring a world where most inhabitants are still not cultivable.

At the beginning of this work, these techniques appeared as promising tools for the phylogenetic identification of the microorganisms, as exemplified by various studies performed on the sequence of the rrs gene, i.e. the 16S rRNA gene according to Riley's nomenclature (1993). Unfortunately, such a technique remains expensive, time-consuming and unavailable to field laboratories, even though the relevant sequences can be successfully obtained by polymerase chain reaction (PCR) amplification from numerous bacteria. It is also not appropriate to track soil-borne or plant-associated microbial communities. To solve these problems, we and others (Gurtler et al., 1991; Navarro et al., 1992; Vaneechoutte et al., 1992, 1993; Ponsonnet and Nesme, 1994a; Nesme et al., 1995; Laguerre et al., 1996; Latour et al., 1996) have proposed to evaluate the validity of the analysis of the restriction fragment length polymorphism (RFLP) of the 16S rRNA gene following its amplification by a PCR-based protocol. Compared to the sequencing technique, the PCR-RFLP analysis appears a priori faster, cheaper and accessible to field laboratories. However, its discriminating capacity has to be appreciated. To address this question, we evaluated the validity, sensitivity and resolution limits of the PCR-RFLP analysis of the 16S RNA gene with respect to the identification of a limited number of bacterial taxa including the genera Agrobacterium amongst the alpha subclass of Proteobacteria, and Xanthomonas, Stenotrophomonas and Pseudomonas amongst the gamma subclass of Proteobacteria. We also report data that showed the suitability of the technique in tracking the biodiversity of microbial communities from the rhizosphere.

\section{MATERIALS AND METHODS}

\subsection{Bacterial strains}

The bacteria investigated by the PCR-RFLP method belonged to readily defined genospecies of Agrobacterium, Pseudomonas (of the so-called P. syringae group), Xanthomonas and Stenotrophomonas characterised by biochemical traits and DNA pairing studies. Strains were from the collection of our laboratories, from the Collection française des bactéries phytopathogènes (CFBP, Inra-Angers, France) and from the Laboratorium voor Microbiologie, Gent Culture Collection (LMG, Gent, Belgium).

Strains were also collected from the root system of the plants by washing the roots in sterile distilled water $\left(10 \mathrm{~mL}\right.$ of water $\mathrm{g}^{-1}$ of root) with vigorous shaking for $1 \mathrm{~min}$. Washed roots were eliminated and dilution series of the bacterial suspensions were performed. Aliquots were plated onto modified LB $(\mathrm{LBm})$ solid medium (Vaudequin-Dransart et al., 1995) supplemented with 
$400 \mu \mathrm{g} \cdot \mathrm{mL}^{-1}$ cycloheximide. Plates were incubated for 1 week at $28^{\circ} \mathrm{C}$ and inspected every day for the appearance of bacterial colonies. Colonies were purified on the same medium to homogeneity.

\subsection{Amplification of the $16 \mathrm{~S}$ gene}

For Agrobacterium and Xanthomonas, the 16S rRNA gene was amplified exactly as described by Nesme et al. (1996), by using genomic DNA isolated by the protocol of Marmur (1961), and the prokaryote specific primers used for PCR-FGPS6 (5'-GGA GAG TTA GAT CTT GGC TCA G- ${ }^{\prime}$ ) and FGPS1509' (5'-AAG GAG GGG ATC CAG CCG CA- $3^{\prime}$ ), designed from the conserved regions of the $16 \mathrm{~S}$ and allowing amplification of $99.5 \%$ of the gene. For Pseudomonas strains, PCR was performed on frozen bacterial pellets processed for $4 \mathrm{~min}$ at $94^{\circ} \mathrm{C}$ ( ca. $10^{7}$ cells per amplification reaction) using the following PCR reaction mixture: Tris-HCl, pH 9.0, $10 \mathrm{mM} ; \mathrm{KCl} 50 \mathrm{mM} ; \mathrm{MgCl}_{2} 1.5 \mathrm{mM}$; dNTP $200 \mu \mathrm{M}$ (each); primers $1 \mu \mathrm{M}$ (each); and Taq DNA polymerase $0.5 \mathrm{U}$ (Appligène, Illkirch, France). Amplification cycles were as follows: $1 \mathrm{~min}$ at $94{ }^{\circ} \mathrm{C}, 1 \mathrm{~min}$ at $55^{\circ} \mathrm{C}$ and $2 \mathrm{~min}$ at $72^{\circ} \mathrm{C}$ completed by a 3 -min elongation at $72^{\circ} \mathrm{C}$. Primers were rD1 (19-mer) and fD1 (20-mer) as described by Weisburg et al. (1991). The 16S rRNA gene from the root-associated bacteria were amplified by adding $4 \mu \mathrm{L}$ ( $c a .10^{5}$ cells per amplification reaction) of a fresh bacterial cell suspension to $100 \mu \mathrm{L}$ of the reaction mixture described later. Cycles were as follows: bacterial cell lysis and DNA denaturation were performed for $5 \mathrm{~min}$ at $95^{\circ} \mathrm{C}$, followed by five amplification cycles $(30 \mathrm{~s}$ at $95^{\circ} \mathrm{C} ; 45 \mathrm{~s}$ at $60^{\circ} \mathrm{C} ; 2 \mathrm{~min}$ at $\left.72^{\circ} \mathrm{C}\right)$ and 30 cycles $\left(1 \mathrm{~min}\right.$ at $95^{\circ} \mathrm{C}, 1 \mathrm{~min}$ at $60^{\circ} \mathrm{C}$ and 2 min at $72^{\circ} \mathrm{C}$ ). Reactions were terminated by a 10-min incubation at $72^{\circ} \mathrm{C}$. The amplification was performed using the set of primers FGPS6 and FGP1509' described earlier. Typically, the PCR reaction mixture consisted of Tris- $\mathrm{HCl}, \mathrm{pH} 9.0,10 \mathrm{mM} ; \mathrm{KCl} 50 \mathrm{mM} ; \mathrm{MgCl}_{2} 1.5 \mathrm{mM}$; gelatine $0.2 \mathrm{mg} / \mathrm{mL}$; dNTP $200 \mu \mathrm{M}$ (each); primers $0.1 \mu \mathrm{M}$ (each); and Taq DNA polymerase $0.4 \mathrm{U}$ (Appligène, Illkirch, France).

\subsection{RFLP analysis}

Restriction digests were performed using different endonucleases following standard procedures and the instructions of the enzyme manufacturers. Reactions were performed in a final volume of 10 to $50 \mu \mathrm{L}$, using 1 to $30 \mu \mathrm{g}$ of PCR products and the relevant amount of restriction enzyme. Restriction fragments were separated in 1.5 to $3 \%$ standard agarose gels. The sizes of the fragments were analysed by comparison with the $123 \mathrm{bp}$ molecular weight marker from Gibco BRL (Gaithersburg, USA) or with a $\Phi$ X174/HaeIII molecular marker (Eurogentec, Seraing, Belgium). Sizes were deduced either by visual inspection or by computer analysis using the software Taxotron (Institut Pasteur, Paris, France), Bioprofil and Biogene (Vilbert-Lourmat, France). The restriction maps of Xanthomonas and Stenotrophomonas were determined from the observed RFLP by comparison with those inferred from published rrs sequences of reference strains. Restriction site differences were analysed by the Wagner parsimony method using the MIX software of the PHYLIP package (Felsenstein, 1993). The number of nucleotide substitutions per nucleotidic site was estimated according to Nei and Li (1979). The distance matrix was used 
to construct dendrograms using methods of Fitch and Margoliash, UPGMA, neighbour-joining and maximum-likelihood as described by Felsenstein (1992). Numerical analysis based on presence/absence of restriction fragments were performed by using the Jaccard coefficient and UPGMA (Sneath and Sokal, 1973).

\subsection{Ribotyping}

Standard ribotyping was performed essentially as previously described by Grimont and Grimont (1986). Bacterial DNA was prepared as described by Glickmann et al. (unpublished report) for Gram-negative bacteria and by the method of Dubnau and Cirigliano (1972) for those exhibiting a variable Gram reaction. Genomic DNA preparations of the clones were submitted to endonuclease digestion using either $E c o \mathrm{RI}, B a m \mathrm{HI}$ or HindIII restriction enzymes. DNA fragments were separated in standard agarose gels. Gels were blotted onto an Amersham Hybond $\mathrm{N}$ membrane using a standard protocol. Hybridisation was carried out essentially as described by Dessaux et al. (1995) using a nonradioactive probe which encompassed the entire 16S rRNA gene sequence of Agrobacterium strain C58. Alternatively, the ribotyping was performed by RFLP analysis of PCR-amplified intergenic spacers lying between the 16S ( rrs) and the 23S rRNA $(r r l)$ genes as previously described (Ponsonnet and Nesme, 1994a, 1994b).

\section{RESULTS AND DISCUSSION}

\subsection{Reliability of the method}

With all the assayed bacteria, the experimental conditions for PCR allowed the amplification of a single band of the expected size. In particular, this was true for the unidentified bacteria isolated from the root system of the plants (data not shown). Digestion of PCR products generally gave unambiguous patterns from which positions of restriction sites could be inferred from the published sequences. In rare instances such as with Stenotrophomonas strains LMG 11002 and LMG 10853, complex patterns were obtained indicating the occurrence of $A l u \mathbf{I}$ and $H p a l l$ dimorphic sites within a single genome (Nesme et al., 1995). This confirms the occurrence of RFLP detectable differences within $r r s$ operons of a given genome as reported in other bacterial species (Mevarech et al., 1989; Gurtler et al., 1991). On the other hand, bacteria belonging to the same genospecies gave identical rrs patterns except for strain LMG 852 of $X$. arboricola pv. pruni, which differed from other members of the species by one restriction site (table $I$ ).

\subsection{Validity of the method}

Results confirm that PCR amplification of $r r s$ is a versatile method that can be used to obtain large copy numbers of this gene from various known and unknown soil-borne and plant-associated bacteria. The analysis of the polymorphism of the restriction fragments of rrs of various organisms led, however, to variable conclusions according to the considered taxa. These are detailed here. 


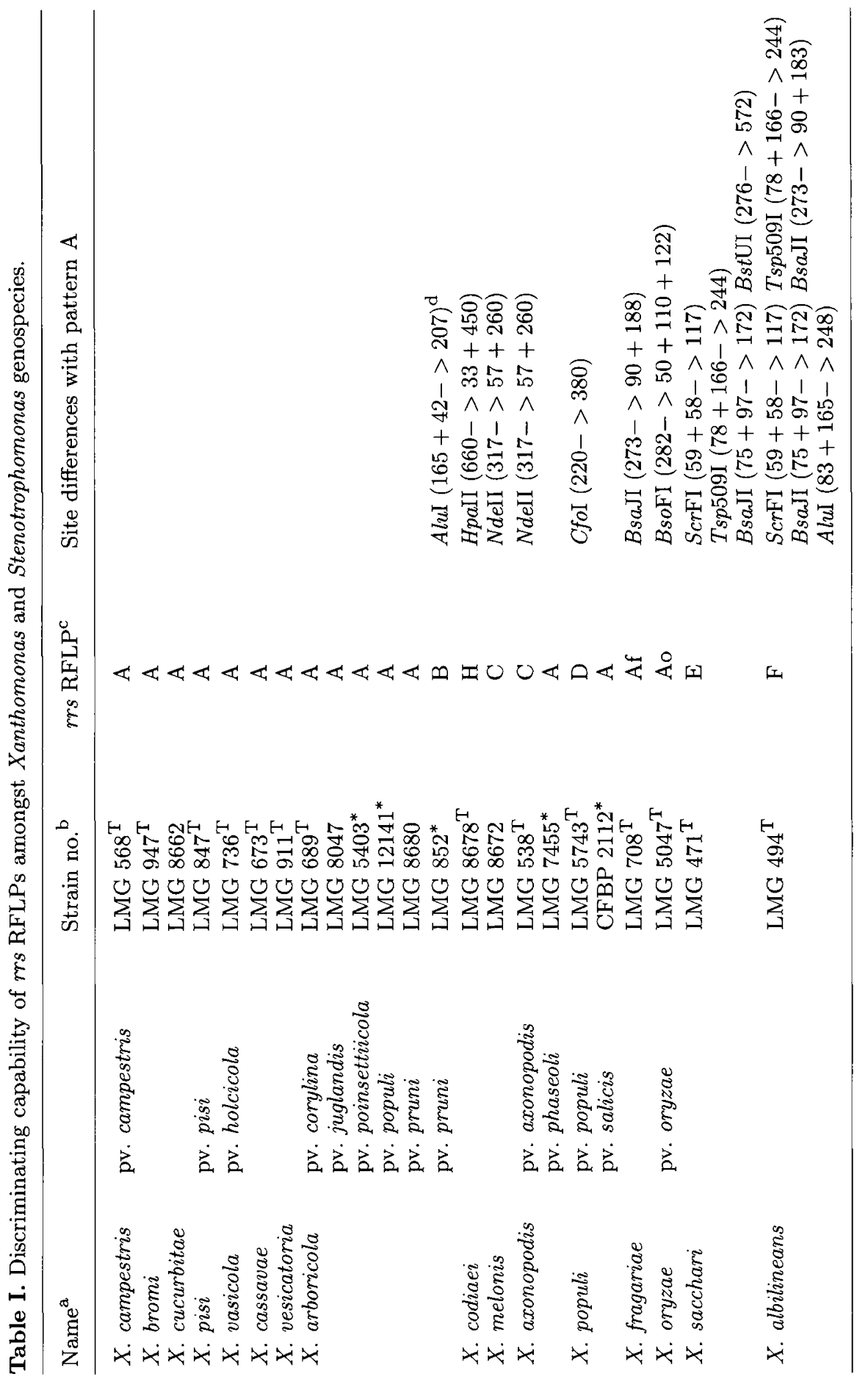




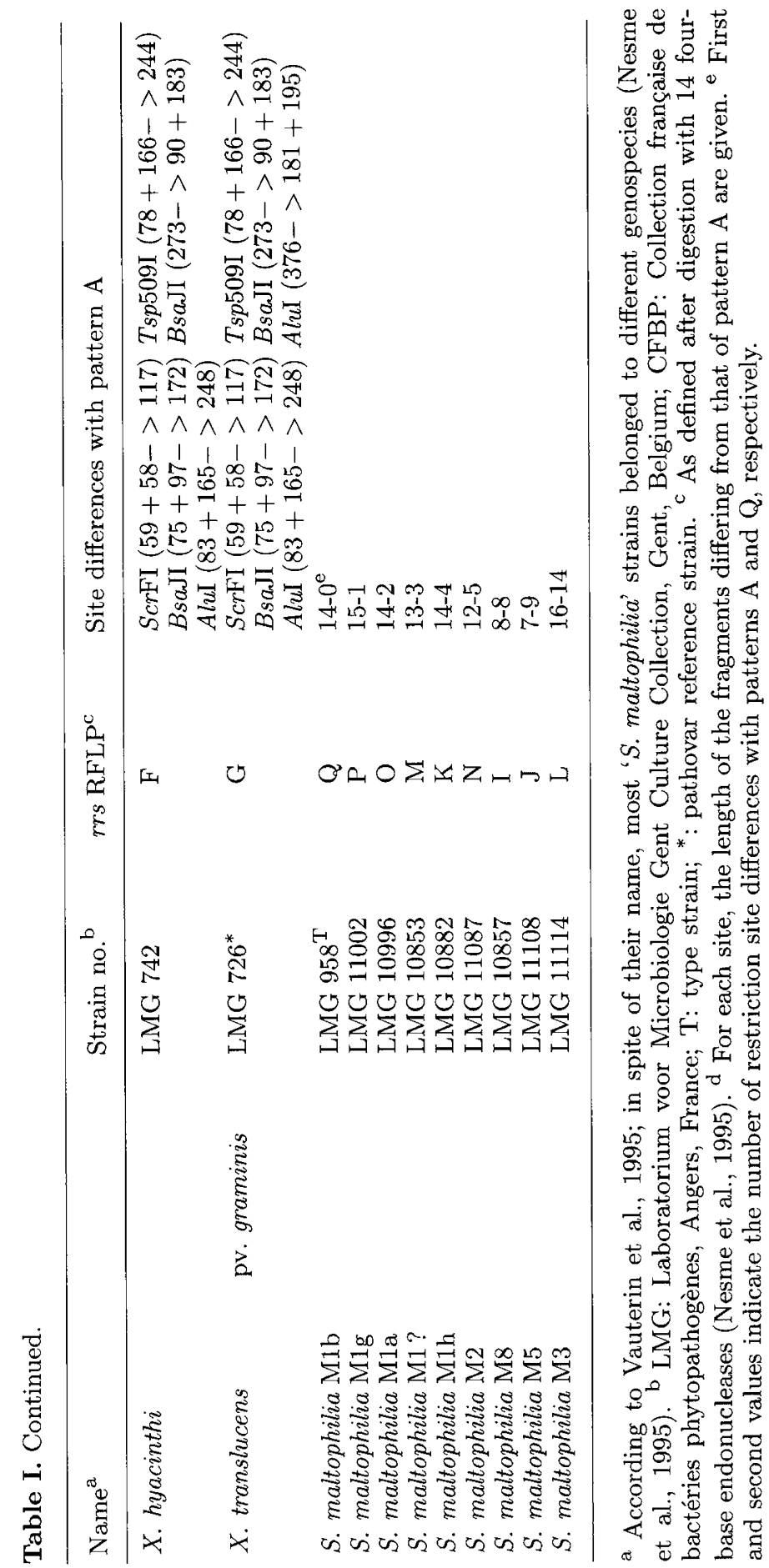




\subsection{Xanthomonas and Stenotrophomonas}

Genera Xanthomonas and Stenotrophomonas belong to the gamma subclass of the Proteobacteria (Woese, 1987). Xanthomonas spp. contains species causing diseases on various plants, while bacteria belonging to the related genus Stenotrophomonas (formerly Xanthomonas maltophilia) are not plant pathogens in spite of their frequent isolation from plant material. Twenty-one genospecies have been delineated among the former genus Xanthomonas (Vauterin et al., 1990, 1995), amongst which 20 were retained in the genus; the others were transferred to the new genus Stenotrophomonas (Palleroni and Bradbury, 1993).

Results of rrs PCR-RFLP analysis with 14 endonucleases showed that the $16 \mathrm{~S}$ genes of the bacteria belonging to the genera Xanthomonas, Stenotrophomonas and Xylella shared 69 common restriction sites. This is much more than the number of sites shared with any other genus of the same subclass (not shown). This result, therefore, confirms the close relatedness of Xylella and Xanthomonas (sensu lato) already shown by Wells et al. (1987). However, eight restriction sites were found almost exclusively in Xanthomonas and Stenotrophomonas spp. and ten exclusively in Xylella, allowing the clear differentiation of the latter genus (Nesme et al., 1995). Numerous genospecies of Xanthomonas could not be differentiated on the basis of their rrs RFLP profiles, and several exhibited only one or two restriction site differences. These results clearly show that the PCR-RFLP method allows only the identification of groups of related species rather than that of well-defined species of Xanthomonas spp. Conversely, all nine strains of Stenotrophomonas yielded distinguishable patterns (table $I$ ). Data were precise enough to provide unambiguous trees of pattern relationships with the parsimony method as well as with distance-based methods, Fitch-Margoliash, neighbour-joining, UPGMA and maximum-likelihood. Furthermore, phylogenetic distances calculated from rrs PCR-RFLP results strongly suggested that several genospecies may exist within the so-called species $S$. maltophilia, a result which exemplifies the discriminative power of the method within this taxon (Nesme et al., 1995).

\subsection{The Pseudomonas syringae group of species}

Results similar to those obtained with Xanthomonas spp. were found for Pseudomonas syringae, a group of oxidase negative species that also belong to the gamma subclass of Proteobacteria (Woese, 1987). The P. syringae group gathers essentially plant pathogenic bacteria. The current classification of this species was originally based on the nature of the host plants infected by the bacteria (Schaad, 1982; Young et al., 1992), a criterion which allowed pathologists to sort isolates into pathovars (strains of the same pathovar were able to infect the same host plants). This classification has recently been reexamined in the light of molecular data. Young et al. (1996) list over 50 pathovars of $P$. syringae, three pathovars of $P$. savastano $i$ and four related species ( $P$. amygdalii, $P$. caricapapayae, $P$. ficuserectae and $P$. meliae). DNA pairing studies indicate that these pathovars and related species indeed fall within nine genospecies (Gardan et al., 1997). 
RFLP of PCR-amplified rrs was analysed by using 13 endonucleases. Eleven enzymes generated near or identical patterns, and only $H m f I$ and $A l u I$ generated more variable patterns. Analysis of 42 strains belonging to the nine genospecies revealed that strains belonging to one genospecies may cluster with strains of other genospecies and may even share identical patterns (figure 1). Surprisingly, however, the rrs-based phenogram is not congruent with the DNA pairing studies, as exemplified by the pv. pisi strain (genospecies 1), which gathers with most members of genospecies 3 in one cluster, and by the pv. persicae strain (genospecies 3), which gathers with most members of the genospecies 1 in a remote cluster. This apparent lack of congruency may be caused by horizontal transfers of rrs from one genospecies to the other after their speciation, or by a high degree of reverse mutations in this gene. Neither hypothesis fits with our view of bacterial evolution. Furthermore, if true, our hypothesis would strongly argue against the application of $r r s$ to ground bacterial phylogeny as proposed by Woese (1987). However, in our opinion, the apparent incongruency of the present results should be considered very cautiously because differences between patterns were not analysed in terms of polymorphic restriction sites (since relevant $r r s$ sequences are lacking) but in terms of restriction fragment length using an automated device. Furthermore, the UPGMA method used to construct dendrograms is not fully appropriate to phylogenetic studies. The above results, however, are consistent with the detection of a very small number of polymorphic restriction sites in $r r s$ and in $r r l$ in the analysed species (Manceau and Horvais, 1997). With these reservations, results obtained with the genospecies related to $P$. syringae are identical to those described earlier with Xanthomonas spp. For both taxa, the rrs PCR-RFLP method can be used only to identify a group of closely related genospecies and not a given genospecies.

That the genospecies of $P$. syringae and related species defined on the basis of DNA pairing studies cannot be differentiated on the basis of distinctive phenotypic characters creates another discrepancy in the classification of this group of bacteria. Taken together, these data and the results generated by rrs PCR-RFLP analysis may impede the recognition of the genospecies defined previously as bona fide new species. However, the current division in nine genospecies remains in agreement with the results obtained by classical ribotype analysis (Gardan et al., unpublished data) and by PCR-RFLP analysis of the intergenic spacer located between $r r s$ and $r r l$ (Manceau and Horvais, 1997). It is tempting to speculate that, in contrast to the slow evolving $r r s$ or $r r l$ genes, noncoding sequences in the vicinity of these genes may constitute 'fast-running molecular clocks' suitable for analysis of the relatednesses of closely related genospecies.

Finally, the identification of six $P$. fluorescens and three $P$. putida biovars (Laguerre et al., 1996; Latour et al., 1996) provides additional information on the method in the genus Pseudomonas. These authors showed that rrs PCR-RFLP analysis and biovar classification is coherent. This suggests that, contrary to what we found with $P$. syringae, a strong polymorphism can be evidenced between members of $P$. fluorescens and P. putida. However, the present classification of the two latter species is based upon biochemical traits and remains uncertain. Thus, in our hands, DNA pairing studies showed that most biovars belong to different genospecies with a rate of DNA pairing 


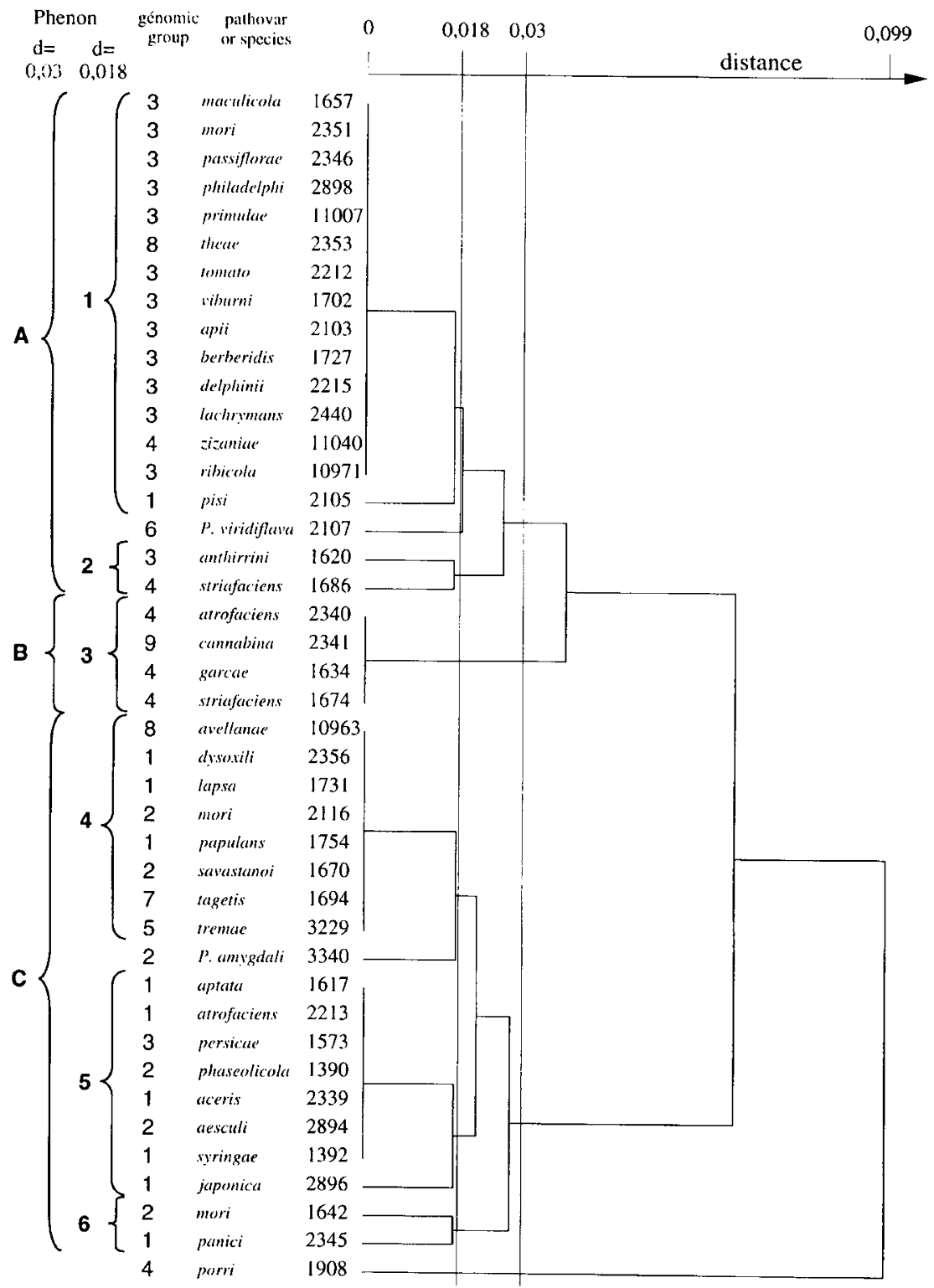

Figure 1. Dendrogram of relatedness of 42 strains of the $P$. syringae group of species.

as low as $10 \%$ within the biovar IV alone (unpublished data). Thus, we assume that the resolution of the method is probably similar whatever the species of Pseudomonas and that inconsistencies merely originated from species definitions, which are based upon DNA pairing with $P$. syringae and related species, and upon biochemical traits with $P$. fluorescens and $P$. putida. 


\subsection{Agrobacterium}

The genus Agrobacterium is a member of the Rhizobiaceae family (Kersters and De Ley, 1984), which has been included in the alpha subclass of Proteobacteria on the basis of ribosomal characteristics (Woese et al., 1984a). Several members of the genus induce hyperplasic disorders in many kinds of plants, which are known as crown gall, hairy root or cane gall diseases. The pathogenicity is almost entirely encoded by transferable Ti or Ri plasmids (Ream, 1989), and the delineation of species was, until recently, based on pathogenic traits (Kersters and De Ley, 1984) encoded by plasmids that are transferable between strains (Van Larebeke et al., 1975). Independently of the plasmid content of the strains, several biovars have been described on the basis of chromosomal (and therefore more stable) characters (Keane et al., 1970; Kersters et al., 1973; Kerr and Panagopoulos, 1977; Holmes and Roberts, 1981). DNA pairing studies showed that different biovars belong to different genospecies (Heberlein et al., 1967; Kersters and De Ley, 1984; Popoff et al., 1984; Ophel and Kerr, 1990). This observation led to a revised nomenclature of the genus (Ophel and Kerr, 1990; Sawada et al., 1993; Bouzar, 1994), in which biovar 1 is now designated A. tumefaciens, biovar 2 A. rhizogenes and biovar 3 A. vitis. A fourth species consisting of only three strains is known as $A$. rubi. In addition, some strains (like NCPPB1650, and AF3.10) can be separated from other agrobacteria to constitute a nuclei around which future Agrobacterium isolates may cluster (Kersters et al., 1973; Bouzar et al., 1995). Nevertheless, the genospecies status of the biovar 1 (characterised by the production of 3-ketolactose) is more complex than generally considered in recent taxonomic revisions. For instance, biovar 1 includes strains like TT111, which is genetically only $50 \%$ homologous with the reference strain B6 (Kersters et al., 1973). The occurrence of nine genospecies within biovar 1 was unequivocally established by Popoff et al. (1984). DNA pairing studies performed using nuclease $\mathrm{S} 1$ and $\Delta T m$ analysis made it possible for these authors to show that strain B6 and bacteria related to TT111 indeed belong to different genospecies. The phylogenetic relationships of members of the genus Agrobacterium were studied by rrs sequencing in several research groups (Sawada et al., 1993; Willems and Collins, 1993; Yanagi and Yamasato, 1993; Bouzar et al., 1995). All identified genospecies of Agrobacterium could be distinguished on the basis of their rrs sequences. Results also showed that the two closely related genospecies defined by strains B6 and TT111 differed by ten nucleotides in their rrs sequences (table II). A similar distance has been detected between a representative strain of $A$. rubi and strain NCPPB1650, which probably belong to different species as judged by the analysis of various phenotypical traits (Kersters et al., 1973). This assertion, however, remains to be confirmed by DNA pairing studies.

Interestingly, that $A$. tumefaciens, A. rhizogenes and $A$. vitis are readily identifiable using rrs PCR-RFLP was demonstrated prior to the availability of the corresponding rrs sequences (Ponsonnet and Nesme, 1994a). Furthermore, several rrs patterns were obtained within members of biovar 1 , confirming the heterogeneity of the taxon. Those empirical results can now be re-evaluated in light of the analysis of the rrs sequences. For this purpose, we performed a computer simulation of rrs restriction with 22 endonucleases available from various manufacturers, recognising a 4-bp sequence. The simulation showed 


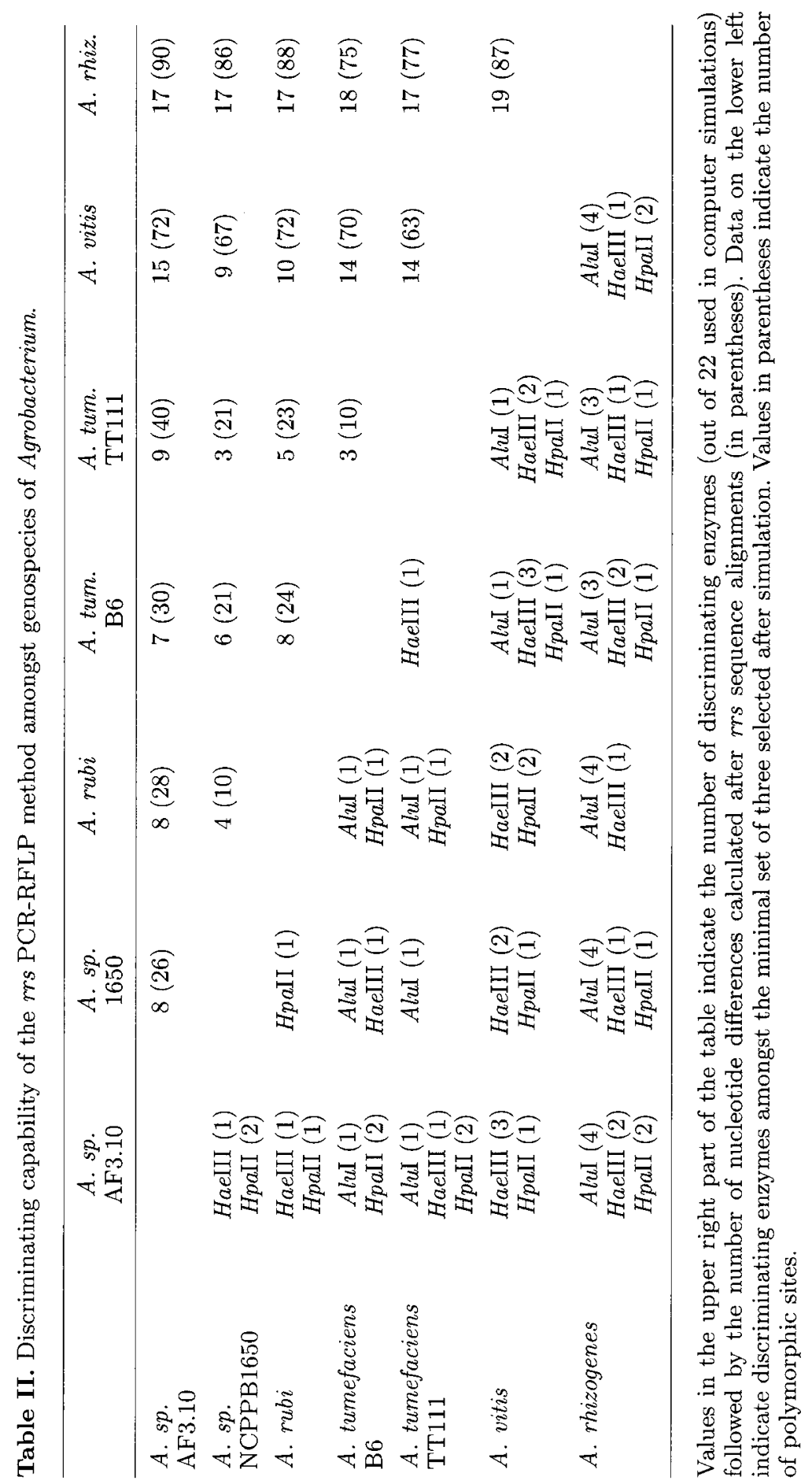


that all the tested sequences can be distinguished by means of $r r s$ PCR-RFLP, even when the number of nucleotide substitutions is as low as ten (e.g. as observed between closely related $\mathrm{B} 6$ and $\mathrm{T} 111$ genospecies or between strain NCPPB1650 and A. rubi; table II). The use of 22 enzymes is not possible for the purpose of routine identification. Thus, considering both the resolution properties of agarose gels (fragments smaller than $75 \mathrm{bp}$ cannot be easily seen in gels) as well as the cost of endonucleases, we found that $H p a \mathrm{II}$ (or $M s p \mathrm{I}$ ), AluI and HaeIII would be the smallest and cheapest set of four-base endonucleases required to identify all the species Agrobacterium on the basis of the RFLP profiles of their rrs gene (table II). With such a limited set of enzymes, the average price for species identification is about 4 ECU per isolate, which is cheaper than every conventional gallery method. Results of the simulation were confirmed with all tested strains (data not shown), and this method is now of routine use in many laboratories studying wild isolates of Agrobacterium spp. In addition, the PCR-RFLP analysis of the ribosomal region consisting of the rrs gene plus the intergenic spacer (IGS, located between $r r s$ and $r r l$, i.e. the 23S rRNA gene) allowed us to obtain both a clear identification of the species of Agrobacterium - by the mean of rrs fragments - and a very accurate typing of the isolates at the strain level - by means of IGS fragments (Ponsonnet and Nesme, 1994b). This PCR-RFLP equivalent of the classical ribotyping coupled to PCR-RFLP analysis of pTi regions now constitutes a powerful tool for epidemiological studies on crown gall dissemination (Pionnat et al., 1996).

Thus, for Agrobacterium spp., the results clearly showed that this method allows the discrimination of strains belonging to different genospecies. The method should also permit the identification of strains of the new Agrobacterium sp., whose original representatives were isolated from galled fig trees in Florida (Bouzar et al., 1995; Vaudequin-Dransart et al., 1995). The sequencing of the rrs of one of these 'fig strains' indeed revealed that the rate of nucleotide substitutions ranged from 1.8 to $2.7 \%$ when the $16 \mathrm{~S}$ rRNA gene of the fig strain was compared to the corresponding genes of $A$. tumefaciens and A. rubi, whereas the rate of nucleotide substitutions of the rrs genes of these two closely related species only reached $1.5 \%$ (Bouzar et al., 1995). This result is of interest since fig strains and $A$. tumefaciens strains were not easily distinguishable on the basis of other morpho-biochemical characters such as total fatty acid composition. The validity of the PCR-RFLP method was also exemplified by the analysis of the Agrobacterium rrs sequences available from the data base. Amongst those, the digestion in vitro and in silico revealed that two of these sequences were obtained from misidentified Agrobacterium strains, originally identified as $A$. tumefaciens. Using a selected set of 12 enzymes, these two isolates were unambiguously associated with other strains of the A. rhizogenes species to which they indeed belong (Oger et al., unpublished data).

Laguerre et al. (1994b) extended the rrs PCR-RFLP analysis to most members of the Rhizobiaceae by examining 48 strains representing the eight recognised Rhizobium species, two new Phaseolus bean Rhizobium, Bradyrhizobium spp., Agrobacterium spp. and unclassified rhizobia from various host plants. Twenty-one composite patterns were obtained from the combined data generated using nine endonucleases. Species assignments were in full agreement with the established taxonomic classification, and the rrs PCR-RFLP method now provides a rapid tool for the identification of root nodule isolates and the 
detection of new data. It can thus be concluded that rrs PCR-RFLP allows the delineation of most species among Rhizobiaceae members.

\subsection{Plant-associated bacteria}

The previously mentioned studies exclusively involved known bacterial species and therefore yielded data on the validity, sensitivity and resolution limit of the PCR- RFLP technique with respect to these species only. Soil-borne and plant-associated bacteria being extremely diverse, we feel that there is a need for a more general evaluation of the validity of the PCR-RFLP technique. To address this question, we took advantage of previous studies performed on bacteria associated with the root system of the legume plant Lotus corniculatus (Oger et al., 1997). These bacteria were first identified using morphological and biochemical criteria. Five morpho-biochemical (MB) groups were evidenced but their precise identification met with limited success. We used this material to investigate whether the PCR-RFLP technique could provide us with more accurate data and whether these would be in agreement with the results of other molecular, high-resolution identification techniques. Restriction enzymes enabling the efficient discrimination of isolates of unrelated species were selected by a computer simulation of the digestion of rrs of four bacteria belonging to the species Escherichia coli, Pseudomonas aeruginosa, Frankia sp. and Agrobacterium tumefaciens. Twelve inexpensive enzymes were retained because they appear to generate quite different restriction patterns. As described earlier, this set of enzymes also allowed the differentiation of four related species of Agrobacterium: A. tumefaciens, A. rubi, A. rhizogenes and $A$. vitis, both in silico and in vitro (Oger et al., unpublished data).

The set of 12 enzymes was used to sort 57 clones isolated from the rhizosphere of Lotus plants. Seventeen RFLP groups were obtained. Most of them exhibited very distinct patterns, whereas others were distinguished only by a single enzyme. In this latter case, the 'molecular proximity' of these bacteria was always correlated with their morpho-biochemical 'proximity' (table III). To validate the classification obtained by the PCR-RFLP technique, we sorted the 57 rhizospheric isolates on the basis of classical ribotyping, using the enzymes EcoRI and HindIII. Results were compared to those generated by the PCRRFLP method. Remarkably, a given ribotype was always associated with a single PCR-RFLP group and was never shared by bacteria exhibiting different rrs patterns. This was also true for the closely related RFLP groups whose delineation relies on the profiles generated by a single restriction enzyme: a given ribotype was clearly associated with each of these closely related PCR-RFLP groups. The reverse proposition, however, was not true. Isolates clustered in a given PCR-RFLP group may exhibit one or more ribotypes. This situation is in full agreement with the results described earlier with Pseudomonas spp.

Some root-associated isolates were identified as Rhizobiaceae and Corynebacterium on the basis of their respective morpho-biochemical characters. Interestingly, an excellent correlation was obtained between the computerised and experimental data for the isolate of the family Rhizobiaceae, which appears to belong to the genus Agrobacterium. Conversely, the rrs PCR-RFLP of the coryneform isolate was completely unrelated to those generated by computer simulation based on the published $16 \mathrm{~S}$ rRNA gene sequence of this genus. 
Table III. Comparison of the classification generated by morpho-biochemical analysis, RFLP of the 16S rRNA gene and ribotyping amongst 57 root-associated bacteria.

\begin{tabular}{lccc}
\hline \multirow{2}{*}{$\begin{array}{l}\text { MB } \\
\text { groups }\end{array}$} & 16S & \multicolumn{2}{c}{ Ribogroups (R groups) } \\
\cline { 3 - 4 } groups & & EcoRI & HindIII \\
\hline MB1 & G3 & nt. & $\mathrm{R}^{\prime} 3$ \\
MB2 & G6a & nt. & $\mathrm{R}^{\prime} 5$ \\
& G6b & R6 & nt. \\
& G6c & R7 & $\mathrm{R}^{\prime} 6, \mathrm{R}^{\prime} 7$ \\
& G6d & R8 & nt. \\
MB3 & G6e & R9 & nt. \\
& G10 & R12 & $\mathrm{R}^{\prime} 10$ \\
MB4 & G11 & nt. & $\mathrm{R}^{\prime} 11$ \\
MB5 & G7 & R10 & $\mathrm{R}^{\prime} 8$ \\
& G1 & R1 to R3 & $\mathrm{R}^{\prime} 1, \mathrm{R}^{\prime} 2$ \\
& G2 & nt. & $\mathrm{nt}^{\prime}$ \\
& G4 & R4 & $\mathrm{R}^{\prime} 4$ \\
& G5 & nt. & $\mathrm{R}^{\prime} 5$ \\
& G8 & R7 & $\mathrm{R}^{\prime} 9$ \\
& G9 & R11 & $\mathrm{R}^{\prime} 4$ \\
& G12 & nt. & nt. \\
& G13 & R13 & $\mathrm{R}^{2} 12$ \\
\hline
\end{tabular}

This table shows the relationships existing between the groups defined by the various methods used in this paper. MB refers to the different morphological/biochemical groups, $16 \mathrm{~S}$ groups to those obtained by PCR-RFLP analysis of the $16 \mathrm{~S}$ rRNA gene, $\mathrm{R}$ and $\mathrm{R}^{\prime}$ groups to the EcoRI and HindIII ribogroups, respectively. Group numbers were arbitrarily given and do not reflect the possible relatedness of the various profiles except for groups G6a to G6e, which are closely related. nt.: not tested.

Within this taxon, however, our experimental patterns appeared related but still dissimilar to those obtained from members of the genus Clavibacter. Interestingly, our isolate and most members of the genus Clavibacter share some morpho-biochemical characters (such as Gram variable staining) and the property of being plant-associated bacteria (Oger et al., unpublished data).

Thus, the PCR-RFLP technique proved to be very useful in sorting unknown plant-associated bacteria. Contrary to what was observed with the $P$. syringae strains, the results obtained by the PCR-RFLP analysis of the $16 \mathrm{~S}$ gene were in excellent agreement with both morpho-biochemical data and ribotyping, though the PCR- RFLP method appeared less discriminate than the ribotyping under our experimental conditions.

Results obtained in this part of the study do not permit us to determine precisely the resolution of the PCR-RFLP technique with bacteria isolated from a community. This question is under further investigation and will be answered only once the relevant microorganisms have been identified (by the analysis of the rrs sequence of a representative member of each $16 \mathrm{~S}$ group). Nevertheless, this shows that the PCR-RFLP technique may be used to discriminate unknown bacterial isolates, a feature which indicates that precise 
identification of bacteria is not always a prerequisite in the assessment of the evolution of microbial communities.

\subsection{Resolution limits of the method}

Clearly, these results showed that differences in rrs are great enough to permit the identification of species of Rhizobiaceae, but only of groups of species closely related to Pseudomonas syringae and Xanthomonas sp. A question then arises: do these results indicate that the $r r s$ molecular clock runs faster in $R h i$ zobiaceae than in Xanthomonadaceae? Perhaps and probably not. Genospecies of Stenotrophomonas and Rhizobiaceae are efficiently distinguishable by the method and both Stenotrophomonas and Rhizobiaceae are isolated from soil or from material which somehow 'trapped' the bacteria. The ecology of Agrobacterium (and that of other Rhizobiaceae), which involves frequent contacts with the soil microflora, would favour the diversity emphasised by the rrs PCRRFLP method and by ribotyping, a case identical to that of the fluorescent Pseudomonas isolated from soils which exhibit very dissimilar rrs PCR-RFLPs (Laguerre et al., 1996a; Latour, 1996). On the other hand, P. syringae and related species as well as pathogenic xanthomonads are very often isolated from plant aerial lesions caused by clonal dissemination of the bacteria but not by trapping from the rich soil reservoir. This latter situation could lead to the frequent isolation of identical or closely related bacterial clones as deduced from the occurrence of bacteria of identical ribotype in different biotopes. In our opinion, the various levels of resolution observed between taxa should be attributed to sampling procedures and bacterial origins rather than to molecular clock differences between taxa. It is therefore tempting to conclude that the resolution limit of the rrs PCR-RFLP method lies at the group of related species. These results might be extended in the near future to the Rhizobiaceae in light of the DNA pairing studies performed by Popoff et al. (1984) on agrobacteria belonging to the biovar 1 .

\subsection{Sensitivity of the method}

The sensitivity of the method could be evaluated by the minimum number of polymorphic restriction sites required to ensure that two bacteria belong to different genospecies. Ideally, this should not depend upon the taxa considered and should be based upon the fact that bacteria of the same genospecies harbour very similar rrs. Some conclusions can be drawn from our empirical results. First, the presence of two polymorphic sites within the rRNA operons of a single bacterial genome clearly showed that a two restriction site difference between the rrs of two bacteria is not sufficient to demonstrate that they belong to different species. The role of the rrs (or rrs product) similarities in taxonomy was clarified by Stackebrandt and Goebel (1994). Their comparative studies indicated that DNA-DNA association studies still remain the superior method that needs to be performed when rrs similarity is $97 \%$ or higher. DNA pairing studies are therefore not required when the rrs sequences differ by 44 nucleotides or more. This also means that at least nine polymorphic restriction sites are required to discriminate unambiguously sequences differing by 44 bases (table IV, figure 2). The proposition of Stackebrand and Goebel is certainly 


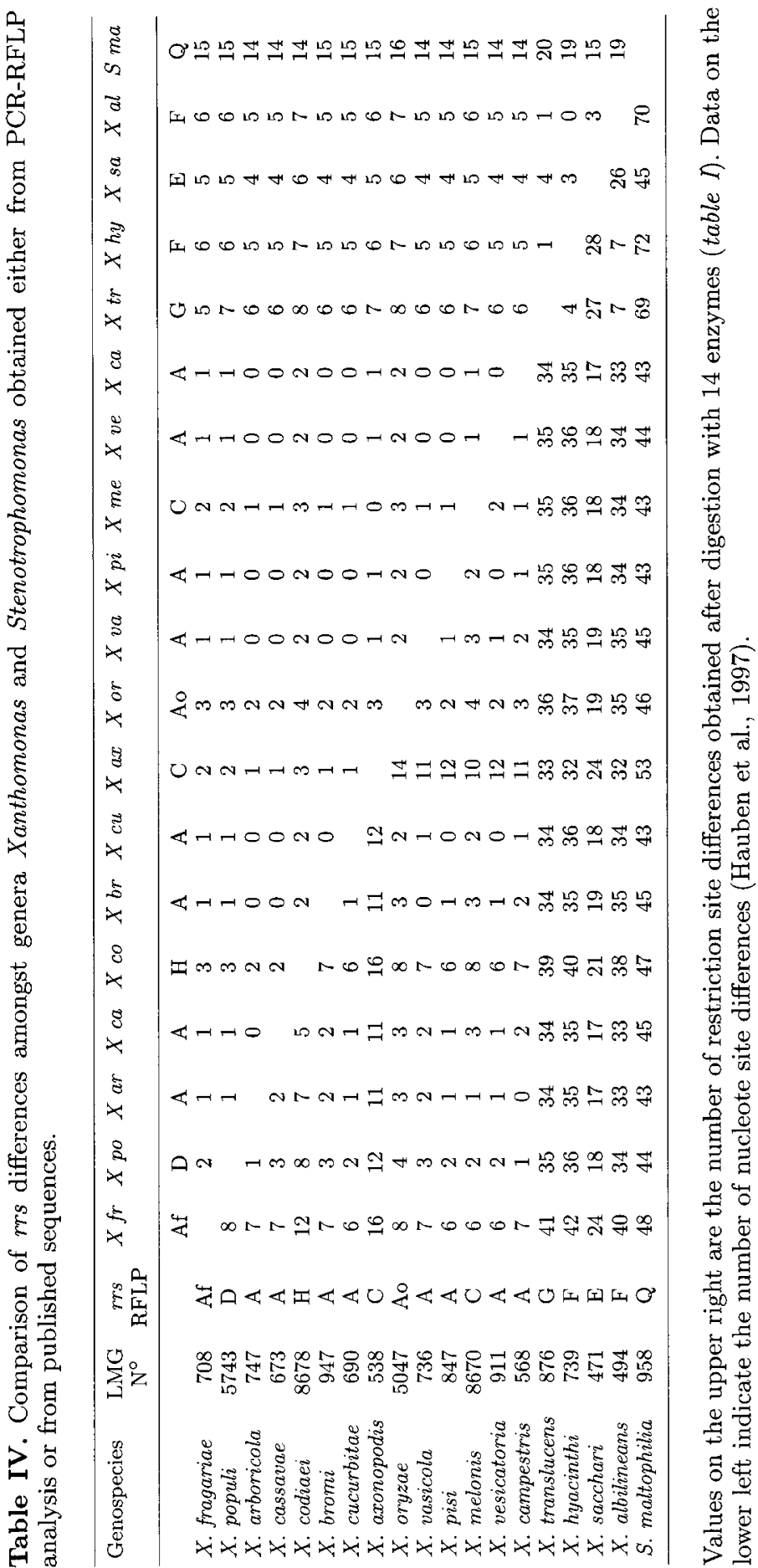




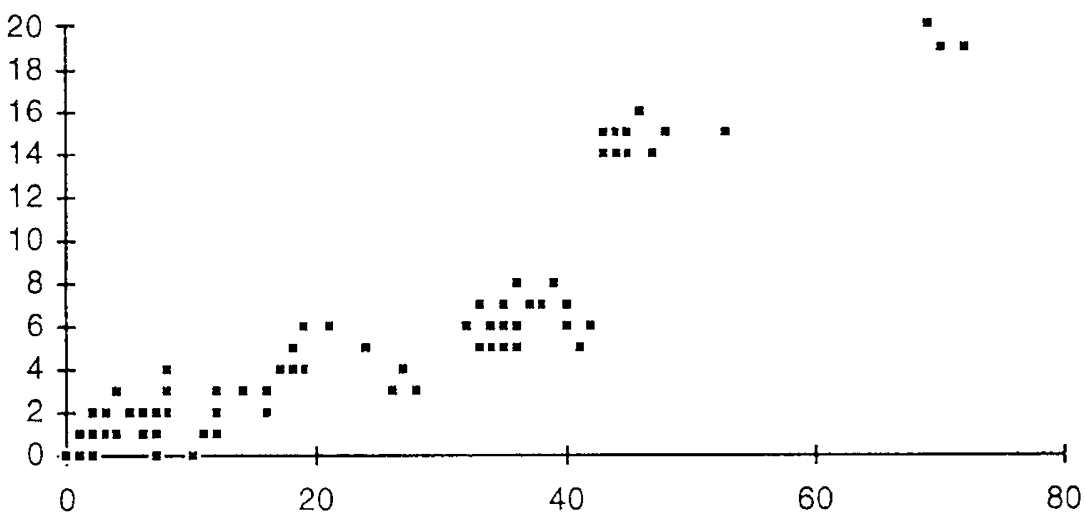

\section{Number of nucleotidic site differences}

Figure 2. Relation between nucleotide site and restriction site differences in rrs amongst genospecies of Xanthomonas and Stenotrophomonas. The rrs (ca. 1485 nucleotides long) were digested after polymerase chain reaction amplification using 14 four-base endonucleases (from data of table IV).

extremely conservative since, in our hands, nine restriction site differences could be obtained between strains of Xanthomonas and Stenotrophomonas or between strains of remote species of Agrobacterium (table II). A less conservative view could be based on our results (Nesme et al., 1995) as well as those of Stackebrandt and Goebel (1994), which both show that rrs similarity lower than $99.3 \%$ (equivalent to at least ten nucleotide substitutions) only occurs between members of different genospecies. From our empirical results obtained with 14 enzymes, five restriction site differences at least are necessary to ensure that two rrs differ by at least ten nucleotides (figure 1). Thus, we propose that five restriction site differences should be sufficient to establish by PCR-RFLP of the 16S rRNA gene(s) that two bacteria belong to different genospecies. Overall, our results strongly support the view that the analysis of the restriction profile of the $16 \mathrm{~S}$ rRNA gene is a rapid and versatile method to analyse known and unknown bacterial populations. The rrs PCR-RFLP study is simpler and faster than sequencing and is suitable for use in almost any laboratory. If sufficient enzymes are used and the positions of the recognition sites are known, the technique should also allow the accurate description of phylogenetic relatedness.

\section{ACKNOWLEDGEMENTS}

The authors wish to thank Marie-Andrée Poirier for skilful technical assistance. P.O. was supported by a fellowship from the Ministère de la recherche et de la technologie. This work was made possible by a grant from the Bureau des Ressources Génétiques to Y.D., L.G. and X.N. 


\section{REFERENCES}

Bouzar H., Request for a judicial opinion concerning the type species of Agrobacterium, Int. J. Syst. Bacteriol. 44 (1994) 373-374.

Bouzar H., Chilton W.S., Nesme X., Dessaux Y., Vaudequin V., Petit A., Jones J.B., Hodge N.C., A new Agrobacterium strain isolated from aerial tumors on Ficus benjamina L., Appl. Environ. Microb. 61 (1995) 65-73.

Dessaux Y., Elasri M., Glickmann E., Oger P., Petit A., Vaudequin-Dransart V., The use of digoxigenin-labelled probes to detect DNA sequences specific for plant pathogenic bacteria, Cell Mol. Biol. 41 (1995) 933-943.

Dubnau D., Cirigliano C., Fate of transforming deoxyribonucleic acid after uptake by competent Bacillus subtilis: size and distribution of the integrated donor sequence, J. Bacteriol. 111 (1972) 488-494.

Felsenstein J., Phylogenesis from restriction sites: a maximum-likelihood approach, Evolution 46 (1992) 159-173.

Felsenstein J., Phylip (Phylogeny Inference Package) version 3.5 c. Distributed by the author, Department of Genetics, University of Washington, Seattle, WA, USA, 1993.

Gardan L., Shafik H.L., Grimont P.A.D., DNA relatedness among pathovars of P. syringae and related bacteria, in: Rudolf K., Burr T.J., Mansfield J.W., Stead D., Vivian A., von Kietzel J. (Eds.), Proceedings of the 5th International Conference on $P$. syringae pathovars and related pathogens, Kluwer Academic Publishers, Dordrecht, (1997) 445-447.

Grimont F., Grimont P.A., Ribosomal ribonucleic acid gene restriction pattern as potential taxonomic tools, Ann. I. Pasteur Microbiol. 137b (1986) 165-175.

Gurtler V., Wilson V.A., Mayall B.C., Classification of medically important clostridia using restriction endonuclease site differences of PCR-amplified 16S rDNA, J. Gen. Microbiol. 137 (1991) 2673-2679.

Hauben L., Vauterin L., Swings J., Moore E.R.B., Comparison of $16 \mathrm{~S}$ ribosomal DNA sequences of all Xanthomonas species, Int. J. Syst. Bacteriol. 47 (1997) 328-335.

Heberlein G.T., De Ley J., Tijtgat R., Deoxyribonucleic acid homology and taxonomy of Agrobacterium, Rhizobium, and Chromobacterium, J. Bacteriol. 94 (1967) 116-124.

Holmes B., Roberts P., The classification, identification and nomenclature of agrobacteria. Incorporating revised descriptions for each of Agrobacterium tumefaciens (Smith \& Townsend) Conn 1942, Agrobacterium rhizogenes (Riker et al.) Conn 1942, and Agrobacterium rubi (Hildebrand) Starr \& Weiss 1943, J. Appl. Bacteriol. 50 (1981) 443-467.

Keane P.J., Kerr A., New P.B., Crown gall on stone fruit. II. Identification and nomenclature of Agrobacterium isolates, Aust. J. Biol. Sci. 23 (1970) 585-595.

Kerr A., Panagopoulos C.G., Biotypes of Agrobacterium radiobacter var tumefaciens and their biological control, Phytopathol. Z. 90 (1977) 172-179.

Kersters K., De Ley J., Genus III Agrobacterium Conn 1942, in: Kieg N.R., Holt J.G. (Eds.), Bergeys Manual of Systematic Bacteriology, Williams \& Wilkins Co., Baltimore, 1984, pp. 244-254.

Kersters K., De Ley J., Sneath P.H.A., Sackin M., Numerical taxonomic analysis of Agrobacterium, J. Gen. Microbiol. 78 (1973) 227-239.

Laguerre G., Rigottier-Gois L., Lemanceau P., Fluorescent Pseudomonas species categorized by using polymerase chain reaction (PCR) restriction fragment analysis of $16 \mathrm{~S}$ rDNA, Mol. Ecol. 3 (1996a) 479-487.

Laguerre G., Mavingui P., Allard R., Charnay M.P., Louvrier P., Mazurier S.I., Rigottier-Gois L., Amarger N., Typing of rhizobia by PCR-DNA fingerprinting and PCR-restriction fragment length polymorphism analysis of chromosomal and 
symbiotic gene regions, application to Rhizobium leguminosarum and its different biovars, Appl. Environ. Microb. 62 (1996b) 2029-2036.

Latour X., Corberand T., Laguerre G., Allard F., Lemanceau P., The composition of fluorescent pseudomonad populations associated with roots is influenced by plant and soil type, Appl. Environ. Microb. 62 (1996) 2449-2456.

Manceau C., Horvais A., Assessment of genetic diversity among strains of Pseudomonas syringae by PCR-restriction fragment length polymorphism analysis of rRNA operons with special emphasis on P. syringae pv. tomato, Appl. Environ. Microb. 63 (1997) 498-505.

Marmur J., A procedure for the isolation of DNA from microorganisms, J. Mol. Biol. 3 (1961) 208-218.

Mevarech M., Hirsch-Twizer S., Goldman S., Yakobson E., Eisenberg H., Dennis P.P., Isolation and characterization of the rRNA gene clusters of Halobacterium marismortui, J. Bacteriol. 171 (1989) 3479-3485.

Navarro E., Simonet P., Normand P., Bardin R., Characterization of natural populations of Nitrobacter spp. using PCR/RFLP analysis of the ribosomal intergenic spacer, Arch. Microbiol. 157 (1992) 107-115.

Nei M., Li W.H., Mathematical model for studying genetic variation in terms of restriction endonucleases, Proc. Natl. Acad. Sci. USA 79 (1979) 5269-5273.

Nesme X., Vaneechoutte M., Orso S., Hoste B., Swings J., Diversity and genetic relatedness within genera Xanthomonas and Stenotrophomonas using restriction endonuclease site differences of PCR amplified 16S rRNA gene, Syst. Appl. Microbiol. 18 (1995) 127-135.

Normand P., Cournoyer B., Simonet P., Nazaret S., Analysis of a ribosomal operon in the actinomycete Frankia, Gene 111 (1992) 119-124.

Oger P., Petit A., Dessaux Y., Genetically engineered plants producing opines alter their biological environment, Nature/Biotechnol. 15 (1997) 369-372.

Ophel K., Kerr A., Agrobacterium vitis sp. nov. for strains of Agrobacterium biovar 3 from grapevines, Int. J. Syst. Bacteriol. 40 (1990) 236-241.

Palleroni N.J., Bradbury J.F., Stenotrophomonas, a new bacterial genus for Xanthomonas maltophilia (Hugh, 1980) Swings et al., 1983, Int. J. Syst. Bacteriol. 43 (1993) 606-609.

Pionnat S., Dessaux Y., Nesme X., Poncet C., Detection and determination of pathogenic Agrobacterium of roses with PCR, Acta Horticulturae 424 (1996) 227-232.

Ponsonnet C., Nesme X., Characterisation of Agrobacterium biotypes by RFLP analysis of PCR-amplified 16S gene, in: Lemattre M., Freigoun S., Rudolph K., Swings J.G. (Eds.), Plant Pathogenic Bacteria, Les Colloques, Éditions Inra, Paris, 66 1994a, pp. 377-381.

Ponsonnet C., Nesme X., Identification of Agrobacterium strains by PCR-RFLP analysis of pTi and chromosomal regions, Arch. Microbiol. 161 (1994b) 300-309.

Popoff M.Y., Kersters K., Kiredjian M., Miras I., Coynault C., Position taxonomique de souches de Agrobacterium d'origine hospitalière, Ann. Microbiol. (I. Pasteur) 135A (1984) 427-442.

Ream W., Agrobacterium tumefaciens and interkingdom genetic exchange, Ann. Rev. Phytopathol. 27 (1989) 583-618.

Riley M., Functions of the gene products of Escherichia coli, Microbiol. Rev. 57 (1993) 862-952.

Sawada H., Ieki H., Oyaizu H., Matsumoto S., Proposal for rejection of Agrobacterium tumefaciens and revised description for genus Agrobacterium and for Agrobacterium radiobacter and Agrobacterium rhizogenes, Int. J. Syst. Bacteriol. 43 (1993) 694-702. 
Schaad N.W., How phytopathogenic bacteria are classified, in: Mount M.S., Lacy G.H. (Eds.), Phytopathogenic Bacteria, vol. 1, Academic Press, San Diego, CA, 1982, pp. 19-29.

Sneath P.H.A., Sokal R.R., Numerical Taxonomy. The Principles and Practice of Numerical Classification, Freeman, San Francisco, CA, 1973.

Stackebrandt E., Liesack W., Goebel B.M., Bacterial diversity in a soil sample from subtropical Australian environment as determined by $16 \mathrm{~S}$ rDNA analysis, FASEB J. 7 (1993) 232-236.

Stackebrandt E., Goebel B.M., Taxonomic note: a place for DNA. DNA reassociation study and 16S RNA sequence analysis in the present species definition in bacteriology, Int. J. Syst. Bacteriol. 44 (1994) 846-849.

Vaneechoutte M., Rossau R., De Vos P., Gillis M., Janssens D., Paepe N., De Rouck A., Fiers T., Claeys G., Kersters K., Rapid identification of bacteria of the Comamonadaceae with amplified ribosomal DNA-restriction analysis (ARDRA), FEMS Microbiol. Lett. 93 (1992) 227-234.

Vaneechoutte M., De Beenhouwer H., Claeys G., Verschraegen G., De Rouck A., Paepe N., Elaichouni A., Portaels F., Identification of Mycobacterium species by using amplified ribosomal DNA restriction analysis, J. Clin. Microbiol. 31 (1993) 2061-2065.

Van Larebeke N., Genetello C., Schell J., Schilperoot R.A., Hermans A.K., Van Montagu M., Hernalsteens J.-P., Acquisition of tumor-inducing ability by nononcogenic agrobactria as a result of plasmid transfer, Nature 255 (1975) 742-743.

Vaudequin-Dransart V., Petit A., Poncet C., Ponsonnet C., Nesme X., Jones J.J., Bouzar H., Chilton W.S., Dessaux Y., Novel Ti plasmids in Agrobacterium tumefaciens strains isolated from fig trees and chrysanthemum tumors and their opine-like molecules, Mol. Plant-Microbe Interact. 8 (1995) 311-321.

Vauterin L., Swings J., Kersters K., Gillis M., Mew T.W., Schroth M.N., Palleroni N.J., Hildebrand D.C., Stead D.E., Civerolo E.L., Hayward A.C., Maraite H., Stall R.E., Vidaver A.K., Bradbury J.F., Toward an improved taxonomy of Xanthomonas, Int. J. Syst. Bacteriol. 40 (1990) 312-316.

Vauterin L., Hoste B., Kersters K., Swings J., Reclassification of Xanthomonas, Int. J. Syst. Bacteriol. 45 (1995) 472-489.

Ward D.M., Weller R., Bateson M.M., 16S rRNA sequences reveal numerous uncultured microorganisms in a natural community, Nature 345 (1990) 63-65.

Wayne L.G., Brenner D.J., Colwell R.R., Grimont P.A.D., Kandler O., Krichevsky M.I., Moore L.H., Murray R.G.E., Stackebrandt E., Starr M.P., Truper H.G., Report of the ad hoc committee on reconciliation of approaches to bacterial systematics, Int. J. Syst. Bacteriol. 37 (1987) 463.

Weisburg W.G., Barns S.M., Pelletier D.A., Lane D.J., 16S ribosomal DNA amplification for phylogenetic study, J. Bacteriol. 173 (1991) 697-703.

Wells J.M., Raju B.C., Hung H.Y., Weisburg W.G., Mandelco-Paul L., Brenner D.J., Xylella fastidiosa gen nov, sp nov, Gram-negative, xylem-limited, fastidious plant bacteria related to Xanthomonas spp., Int. J. Syst. Bacteriol. 37 (1987) 136-143.

Willems A., Collins M.D., Phylogenetic analysis of rhizobia and agrobacteria based on 16S rRNA gene sequences, Int. J. Syst. Bacteriol. 43 (1993) 305-313.

Woese C.R., Bacterial evolution, Microbiol. Rev. 51 (1987) 221-271.

Woese C.R., Stackebrandt E., Weisburg W.G., Pater B.J., Madigan M.T., Fowler V.J., Hahn C.M., Blanz P., Gupta R., Nealson K.H., Fox G.E., The phylogeny of purple bacteria, the alpha subdivision, Syst. Appl. Microbiol. 5 (1984a) 315-326.

Woese C.R., Blanz P., Hahn C.M., What isn't a pseudomonad, the importance of nomenclature in bacterial classification? Syst. Appl. Microbiol. 5 (1984b) 179-195.

Yanagi M., Yamasato K., Phylogenetic analysis of the family Rhizobiaceae and related bacteria by sequencing of $16 \mathrm{~S}$ rRNA gene using PCR and DNA sequencer, FEMS Microbiol. Lett. 107 (1993) 115-120. 
Young J.M., Takikawa Y., Gardan L., Stead D.E., Changing concepts in the taxonomy of plant pathogenic bacteria, Annu. Rev. Phytopathol. 30 (1992) 67-105.

Young J.M., Saddler G.S., Takikawa Y., De Boer S.H., Vauterin L., Gardan L., Gvozdak R.I., Stead D.E., Names of plant pathogenic bacteria 1864-1995, Rev. Plant Pathol. 75 (1996) 721-763. 